and the Book Jobber: The Marketing of a New Collection Development Service," by Forrest E. Link; "Trends Affecting Vendor Selection: One Academic Library's Experience," by Twyla Mueller Racz and Trudie A. Root of Eastern Michigan University; "Foreign Acquisitions: Frustration and Fun!" by Linda S. Vertrees; and "Choice at a Distance: A Footnote for an Official History," by Robert S. Bravard, on the controversial Choice editor Peter Doiron. Copies are available for $\$ 29.95$ from Haworth Press, 10 Alice St., Binghamton, NY 13904-1580. ISBN 1-56024-121-7.

- Who's Who of Women in World Polities (311 pages, 1991) features more than 1,500 biographies of prominent women politicians worldwide. To be included in the book, an individual must be either head of state, a member of government, a member of the national legislature, a party or trade union leader, a regional leader, or mayor of a large city. Statistics on female share of cabinet-level posts by country are given, along with such historical data as year of women's enfranchisement. The volume may be purchased for $\$ 95.00$ from K. G. Saur, P.O. Box 31, New Providence, NJ 07974-9903. ISBN 086291-627-5.

- Your Buried Treasures: Can You Find Them? by Marjorie Thomas Payne (24 pages, September 1991), designed as a guide for creating a personal records plan, features a detailed records retention and destruction schedule, a bibliography and reading list, and an extensive index. Copies are available for $\$ 7.50$ (discounts given for large quantities) from C. Berger and Company, P.O. Box 274, Wheaton, IL 60189.

\title{
Optical local area network at Walla Walla College
}

Installation of an optical network at Peterson Memorial Library, Walla Walla College, has proved to be popular among students and faculty. A 1990 fall survey of students using the networked LaserCats elicited these overwhelmingly positive comments: "They're great!" and "I like it, thanks for getting them." Grants totalling \$28,759 from the college's Committee of 100 funded the two-year project.

Librarians at Peterson were looking for an inexpensive way to provide computerized access to their collections. Key personnel at the Campus Computer Center suggested developing an optical network allowing multiple access to CD-ROM products. They knew we were already using LaserCat, a CD-ROM version of Westem Library Network's bibliographic database, and thought it a prime candidate. LaserCat provides access to the holdings of over 496 public, special, research, and academic libraries, including Peterson's. As of December 1991, 3.7 million records were available through LaserCat. WLN member libraries are concentrated in the Pacific Northwest. Peterson has been using Western Library Network as their bibliographic utility since 1980 .

By November 1990 the optical network had become a reality. Using LaserCat as the library's main catalog, patrons can execute exact, keyword, or browse searches. Six public access workstations are located in the library. Five of them are dedicated to operating LaserCat. A sixth, added in September 1991, supports Academic Abstracts, a CD-ROM index covering 769 academic and general periodicals. Workstations share printers. Signs naming the CD product in operation cover the floppy disc drives on each workstation, effectively eliminating problems with students trying to access the campus network for other purposes. To bring the system up each morning, Network and CD product software are automatically loaded onto the library's computers. Over 400 computers located in student PC labs and faculty offices have shared access to both products through the main campus network.

The optical network consists of the server, a Dell $386 \mathrm{PC}$, and 6 Toshiba 3200 CD-ROM drives, which are connected to the campus' ethernet network backbone. OptiNet software drives the server. Novell's NetWare is the operating system for the larger campus network. Twisted-pair cabling provides the basic infrastructure.

Because of the success of our optical network, Walla Walla High School Library used increased funding for technology, provided by the school district, to install an optical network modelled after ours. Since the fall of 1991, their students have had access to Wilson's Reader's Guide and General Science Index.

Response time is slower on the optical networks because CD-ROM products execute searches more slowly than an automated system does. The major problem we have experienced with the optical network, however, occurs when campus network operating software is upgraded. Such upgrades have inadvertently affected not only the operation of the optical network but access to it by older PCs. Our Campus Computer Center personnel have found that a thorough re-examination of the optical network is needed after all regular network upgrades. Over all, though, we have been quite pleased with the performance of our optical networkCarolyn Gaskell, Peterson Memorial Library, Walla Walla College 


\section{When quality}

\section{and service count...}

\section{More libraries are}

\section{counting on}

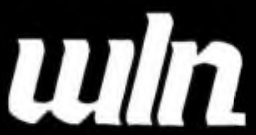

\section{For database preparation and authority control:}

$\checkmark$ WLN MARC Record Service (MARS)ru:

Complete database preparation including duplicate deletion, holdings merging, record upgrade, item record conversion and smart bar codes.

$\checkmark$ Authority control: LC NAF/SAF or WLN authority file matching and heading upgrade; manual review; output of USMARC authority records.

$\checkmark$ Retrospective conversion: Shelflist conversion and non-MARC to MARC record conversions and upgrades.

$\checkmark$ Output products: Your upgraded bibliographic records and USMARC authority records on MARC tapes or CD-ROM catalogs.

\section{For collection assessment services:}

\section{For online and CD-ROM databases:}

WLN Online System: Over 7 million bibliographic records under full authority control; powerful searching: sophisticated online cataloging; online LC NAF/SAF File; full-feature Interlibrary Loan and Acquisitions Systems; MARC record download or tape to local systems.

$\checkmark$ LaserCat8: A 3.6 million record database on CD.ROM; catalog card, label, bibliography printing: MARC record downloading to local systems; powerful searching; original cataloging; retrospective conversion.

$\checkmark$ LaserPacrw: This public access version of LaserCat provides your bibliographic records and holdings including individual call numbers and cross references. The ideal calalog both for individual libraries and consortia.
WLN Conspectus Service: A nationally recognized method for assessing both Dewey and LC classified collections. WLN's Conspectus software lets you build your own assessment database and print your own reports.

$\checkmark$ WLN Collection Analysis Reports: OHers precision analysis of your collection by Conspectus subject categories, date ranges and a variety of other criteria. A powerful co lection analysis tool for single institutions or groups

$\checkmark$ WLN BCL3 Service: Compares your collection against the 3rd edition of Books for College Libraries accurately and efficiently. Miss, match and close match reports can be arranged by BCL3 number order or Conspectus subject categories.

Comprehensive. High quality. Flexible. Affordable. That's what librarians are saying about WLN. Isn't it time you put WLN products and services to work for you? WLN, 4224 6th Ave., Bldg. 3, Lacey, WA 98503 1-800-DIALWLN (206) 459-6518 FAX (206) 459-6341 